\title{
Distressed Firms and Dividend Reductions
}

\author{
Steven C. Hall ${ }^{1}$, Vipin K. Agrawal ${ }^{2}$ \& Pushpa Agrawal ${ }^{1}$ \\ ${ }^{1}$ Department of Accounting, Finance, and Economics, University of Nebraska at Kearney, USA \\ ${ }^{2}$ Department of Finance, University of Texas at San Antonio, USA \\ Correspondence: Steven C. Hall, Department of Accounting, Finance, and Economics, University of Nebraska at \\ Kearney, USA
}

Received: January 11, 2019

Accepted: February 20, $2019 \quad$ Online Published: February 23, 2019

doi:10.5430/afr.v8n1p222

URL: https://doi.org/10.5430/afr.v8n1p222

\begin{abstract}
We are interested in the effects of dividend reduction decisions on the firms that make them. Research shows that dividends tend to follow earnings as earnings increase but are less likely to follow earnings down. We speculate that there must be a cost associated with dividend reductions that cause this reluctance to decrease dividends as earnings decline. We form several hypotheses related to potential costs. To test these hypotheses, we examine changes in various financial ratios in each of the three years following a reduction in dividends. We also compare the changes in financial ratios of distressed dividend-reducing firms to those of distressed firms that did not reduce dividends and of non-distressed dividend-reducing firms to those of non-distressed firms that did not reduce dividends. Results do not indicate that there are costs, but rather, benefits of dividend reductions to both distressed and non-distressed firms. We find one cost of reducing dividends to non-distressed firms, i.e., a drop in the market value of the firm in the year following the dividend reduction.
\end{abstract}

Keywords: distressed firms, dividend reduction

\section{Introduction}

We are interested in the costs of dividend reductions on distressed and non-distressed firms. Research indicates that firms make dividend decisions to signal future earnings expectations and to distribute residual earnings or cash flows (Aharony and Swary, 1980 and Baker and Smith, 2006, for examples). Research also shows that dividends tend to follow earnings as earnings increase but are less likely to follow earnings down, that there is a reluctance to reduce dividends (DeAngelo and DeAngelo, 1990). We speculate that there are costs and benefits to dividend reductions and those costs may help explain the reluctance to reduce dividends. We also speculate that costs of dividend reductions differ between firms that are in distress and those that are not.

\section{Dividends and Effects of Dividend Reduction on the Firm}

The two primary explanations for dividend payout are (1) to distribute excess cash to the shareholders and (2) to signal to investors management's assessment of future cash flows and investment opportunities. There is general agreement in the literature that dividends seem to follow earnings as earnings increase, but there is a general reluctance to reduce dividends as earnings fall. Such a tendency would be difficult to explain if we focused exclusively on the notion that the purpose of dividend payout is to distribute excess cash. However, it is not surprising relative to the notion of signaling.

When a dividend is initiated or increased the signal to investors is a positive signal. Earnings and cash flows can be maintained or increased in the future, and since dividends are rarely decreased, those earnings and cash-flow implications are for an indefinite period into the future. It has been shown that the market reacts positively to such news and the rewards are positive to the manager (e.g., Healy and Palepu, 1988, Michaely et al, 1995, Brooks et all, 1998, Grullon et al, 2002, and Lee and Yao, 2003). On the other hand, dividend omissions or reductions have the opposite effect in both the signal and the effect. The negative market reaction to dividend reductions is greater in magnitude than the positive reaction to dividend increases. We are interested in concurrent and longer-term effects on the firm that result from a reduction in dividends.

We look at dividend reduction of distressed and non-distressed firms separately. These are different decisions and may effect firms differently. For example, distressed firms may make the decision to reduce dividends because of binding dividend constraints in debt agreements. Distressed firms have been shown to have higher dividend payout 
rates (Cohen and Yagil, 2009). Signaling and smoothing incentives will have less effect on distressed firms. Bankruptcy risk will have different implications for distressed firms. Strategic incentives to cut dividends may be different for distressed and non-distressed firms.

\section{Hypotheses}

This section develops hypotheses regarding the effects of dividend reductions on firms. There is some discussion about how the effect might be different for distressed and non-distressed firms as well.

\subsection{Effect on Market Value}

As noted, event studies of dividend reductions report a negative market effect for dividend reductions. For a firm that is not distressed the signal could be that earnings and cash flows will be lower in the future, that there are reduced investment opportunities. However, the firm also could be making the dividend reduction decision to conserve cash for a new investment opportunity.

For distressed firms, the dividend reduction may be in response to binding dividend constraints in the firms' debt contracts. The firm is unable to maintain earnings at a level to avoid this debt-contracting cost. The effect on market values may be mitigated by the fact that the reduction would not be unexpected.

We measure the market-value effect with two ratios, market value to sales and market value to book value. We predict that the effect will be smaller with distressed firms since the financial difficulty leading to the dividend reduction should already be impounded in the stock price.

$\mathrm{H}_{1}$ : Firms that reduce dividends will have lower market values and more negative changes in market values following a dividend reduction than firms that did not reduce dividends.

\subsection{Opportunity}

Firms that reduce dividend payout will have more cash than they would otherwise and, thus, will have more opportunity to invest. We measure the opportunity effect with the ratio of capital expenditures to total assets. We predict that dividend reducing firms will have higher capital expenditures than firms that do not reduce dividends. We expect the effect to be more pronounced in non-distressed firms, since distressed firms may be more likely to reduce capital expenditures as a result of financial distress independent of the dividend decision.

$\mathrm{H}_{2}$ : Firms that reduce dividends will have greater capital expenditures than firms that did not reduce dividends.

\subsection{Liquidity}

Firms that reduce dividends will have more cash or less debt than if they had used the cash or borrowed money to pay a dividend. Thus, the direct effect on the firm will be an increase in liquidity. On the other hand, the lack of liquidity may have initiated the dividend reduction. We measure liquidity as cash to total assets.

$\mathrm{H}_{3}$ : Firms that reduce dividends will have higher liquidity than firms that do not.

\subsection{Capital}

Since firms are reluctant to reduce dividends, a reduction by distressed firms signals an inability to produce cash flows sufficient to avoid binding dividend constraints or other factors that force the dividend cut. Such firms will find it more difficult to raise needed capital. Distressed firms that reduce dividends may lose the power to raise capital required to remain viable. Without financial backers, these firms are more likely to fail. We measure the firm's ability to raise capital with sales growth, total liabilities to common stockholders' equity, and retained earnings to total stockholders' equity.

$\mathrm{H}_{4}$ : Distressed firms that reduce dividends will have more difficulty raising capital relative to distressed firms that do not reduce dividends and relative to non-distressed firms.

\subsection{Profitability}

Distressed firms may be obligated to reduce dividends due to debt contracting constraints, e.g., a binding dividend constraint or risk of default. Reduced appeal for the firms' products may follow. Non-distressed firms are not expected to experience the same effect. We measure profitability with return on assets.

$\mathrm{H}_{5}$ : Distressed firms that reduce dividends will experience reduced profitability relative to distressed firms that do not reduce dividends and relative to non-distressed firms.

Table 1 describes the variables used in the study. 


\section{Method and Data}

Our sample of firms in categorized into four groups, i.e., distressed firms that reduced dividends, distressed firms that did not reduce dividends, non-distressed firms that reduced dividends, and non-distressed firms that did not reduce dividends. For each group, we calculated the change in each financial ratio for each of the three years following the dividend reduction. We use one-sample t-tests assuming mean differences of zero to test for the effect of the dividend reduction on the ratios in each group. We use a two-sample t-test for differences of means to compare the changes in each ratio between groups.

Table 1. Financial ratio definitions

\begin{tabular}{cl}
\hline Financial Ratio & Definition \\
\hline Market Value: & \\
Market/Sales & Market value of firm equity at year-end divided by total sales for the year. \\
Market/Book & Common share price at year-end divided by the book value per share. \\
Opportunity: & \\
CapEx/TA & Capital expenditures for the year divided by total book value of assets at year-end. \\
Liquidity: & \\
Cash/TA & Cash at year-end divided by total book value of assets. \\
Raising Capital: & \\
$\begin{array}{c}\text { Sales Growth } \\
\text { TL/TA }\end{array}$ & Sales less prior year sales all divided by prior year sales. \\
RE/TSHE & Total liabilities at year-end divided by common stockholders' equity. \\
Profitability: & \\
ROA & Income before taxes, depreciation, and extraordinary items divided by average assets.
\end{tabular}

We used two alternative definitions of distress that are found in the literature (Bhagat et al, 2005 and Altman, 1968). First, we defined stress as two successive years of reporting a net loss. The alternative measure of distress used the Altman's Z-score (Altman et al, 2013). Altman estimates the financial health of a firm using an overall index Z, where:

$$
\mathrm{Z}=0.717 \mathrm{X} 1+0.847 \mathrm{X} 2+3.10 \mathrm{X} 3+0.420 \mathrm{X} 4+0.998 \mathrm{X} 5 \text {, }
$$

and where $\mathrm{X} 1$ is the working capital to total assets, $\mathrm{X} 2$ is the retained earnings to total assets, $\mathrm{X} 3$ is the ratio of earnings before interest and tax to total assets, $\mathrm{X} 4$ is the book value of equity to total liabilities, and X5 is sales to total assets. The distressed condition is defined as having an Altman's Z-score less than 2.675.

We obtained our data from Compustat, 1984-2014. We deleted regulated industries. We also deleted firms that had less than three years of stable or increasing dividends. The result was 2,371 dividend paying companies and 46,374 firm-years. We defined a dividend-reducer as a firm that reduced dividends by at least $10 \%$ from the previous year. That gave us 4,785 firm-years with dividend reductions. Data availability to determine distress and non-distress using the two different definitions of distress also reduced the number of firms available for analysis. Table 2 gives the number of firm/years used in our analysis for each of the firm distressed/non-distressed dividend reduced/dividend not reduced categories.

Table 2. Number of Firm Years Used in Our Tests

\begin{tabular}{lll}
\hline & Dividends Reduced & Dividends Not Reduced \\
\cline { 2 - 3 } Distressed by 2 years of losses & 403 & 433 \\
Not distressed by 2 years of losses & 4,383 & 41,156 \\
Distressed per Altman's Z-score & 1,247 & 10,838 \\
Not distressed per Altman's Z-score & 667 & 6,679 \\
\hline
\end{tabular}




\section{Results}

Results of our tests are mixed relative to predictions. They are reported in Tables 3-10.

\subsection{Effect on Market Value}

Tables 3 and 4 report the results of our tests of the changes in market value relative to the year of the dividend reduction. Contrary to our expectations, there is some indication that market value increases for distressed firms that reduce dividends. Whether we measure distress as two consecutive years of losses or measure distress using Altman's Z-score, and whether we measure market value as the ratio of market value to sales or the ratio of market value to book value, there is a significant increase in market values in the years following a dividend reduction by distressed firms. When comparing the changes in market value of distressed firms that reduced dividends with distressed firms that did not, the results are not as strong. However, in both of the Z-score models, market value changes are significantly greater for the dividend reducing firms.

There is some evidence that non-distressed firms experience a decline in value in the year following the dividend reduction. The only significant finding is in the market to sales ratio test based on the Z-score.

Table 3. Comparison of changes in Market/Sales Ratio

\begin{tabular}{lcccc}
\hline based on two years losses & & & \\
& & & \\
& Year 0 & Year 0-1 & Year 1-2 & Year 2-3 \\
\cline { 2 - 5 } Distressed, Reduced (5) & 0.9511 & $0.2530^{* * *}$ & $0.2150^{* * *}$ & $0.2058^{* *}$ \\
Distressed, Not Reduced (6) & 1.7586 & 0.1119 & $0.1234^{* *}$ & $0.1655^{* * *}$ \\
Not Distressed, Reduced (7) & 2.6934 & -0.1236 & 0.0870 & -0.0004 \\
Not Distressed, Not Reduced (8) & 2.0749 & -0.0171 & 0.0217 & 0.0054 \\
Distressed, Reduced vs. Distressed, Not Reduced (5-6) & $-0.8075^{* * *}$ & 0.1412 & 0.0916 & 0.0403 \\
Not Distressed, Reduced vs. Not Distressed, Not & $0.6185^{* * * *}$ & -0.1065 & 0.0654 & -0.0058 \\
Reduced (7-8) & & & & \\
\hline based on z-score & & & & \\
\hline & Year 0 & Year 0-1 & Year 1-2 & Year 2-3 \\
\cline { 2 - 5 } Distressed, Reduced (5) & 1.1689 & $0.0629^{* *}$ & 0.0047 & $0.1024^{* * *}$ \\
Distressed, Not Reduced (6) & 1.3498 & 0.0019 & $0.0477^{* * *}$ & -0.0020 \\
Not Distressed, Reduced (7) & 2.2096 & $-0.1528^{* *}$ & -0.0286 & 0.0194 \\
Not Distressed, Not Reduced (8) & 1.4506 & -0.0176 & 0.0168 & 0.0041 \\
Distressed, Reduced vs. Distressed, Not Reduced (5-6) & $-0.1809^{* * *}$ & $0.0610^{* *}$ & -0.0429 & $0.1045^{* * *}$ \\
Not Distressed, Reduced vs. Not Distressed, Not & $0.7590^{* * * *}$ & $-0.1352^{* *}$ & -0.0454 & 0.0153 \\
Reduced (7-8) & & & & \\
\hline
\end{tabular}

Notes: One tail t-test, $* 10$ percent level, $* * 5$ percent level, and $* * * 1$ percent level 
Table 4. Comparison of changes in Market/Book Ratio

\begin{tabular}{|c|c|c|c|c|c|}
\hline \multicolumn{6}{|l|}{ based on two years losses } \\
\hline & & Year 0 & Year 0-1 & Year 1-2 & Year 2-3 \\
\hline Distressed, Reduced (5) & & 1.2317 & $0.3498 * * *$ & $0.0887^{*}$ & $0.3766 * * *$ \\
\hline Distressed, Not Reduced (6) & & 1.8281 & $0.1873^{*}$ & $0.2502 * *$ & 0.0050 \\
\hline Not Distressed, Reduced (7) & & 20.7459 & 3.9202 & -5.1836 & 5.3501 \\
\hline Not Distressed, Not Reduced (8) & & 4.2581 & -0.7808 & 0.4226 & 1.3394 \\
\hline Distressed, Reduced vs. Distressed, Not Reduced (5-6) & & $-0.5964 * * *$ & 0.1625 & -0.1615 & $0.3716 * * *$ \\
\hline $\begin{array}{l}\text { Not Distressed, Reduced vs. Not Distressed, } \\
\text { Reduced }(7-8)\end{array}$ & Not & $16.4878 * * *$ & 4.7010 & -5.6062 & 4.0169 \\
\hline \multicolumn{6}{|l|}{ based on z-score } \\
\hline & & Year 0 & Year 0-1 & Year 1-2 & Year 2-3 \\
\hline Distressed, Reduced (5) & & 2.1632 & $0.3002^{*}$ & 0.1122 & 0.2567 \\
\hline Distressed, Not Reduced (6) & & 2.7523 & -0.1651 & -0.0591 & 0.0157 \\
\hline Not Distressed, Reduced (7) & & 82.6255 & 14.0190 & -24.0397 & 27.2764 \\
\hline Not Distressed, Not Reduced (8) & & 3.5372 & -0.0138 & 0.1465 & 0.0522 \\
\hline Distressed, Reduced vs. Distressed, Not Reduced (5-6) & & $-0.5891 * * *$ & $0.4653 * *$ & 0.1713 & $0.2410 *$ \\
\hline $\begin{array}{l}\text { Not Distressed, Reduced vs. Not Distressed, } \\
\text { Reduced }(7-8)\end{array}$ & Not & $79.0883 * * *$ & 14.0328 & -24.1861 & 27.2242 \\
\hline
\end{tabular}

Notes: One tail t-test, $* 10$ percent level, $* * 5$ percent level, and $* * * 1$ percent level

\subsection{Opportunity}

Table 5 reports the results of our tests of the ratio of capital expenditures to total assets. In the model that defines distress as two consecutive years of losses, capital expenditures for distressed firms increase in the three years after a dividend reduction and significantly so in year 2 . However, compared to firms that did not reduce dividends, capital expenditures are significantly higher in year 2 but significantly lower in year 3 . In the Z-score model, dividend reducers have a greater increase in capital expenditures in all three years but significantly so only in year 3 . These results provide some evidence to support our hypothesis.

For non-distressed firms, using the two years of losses model, firms that reduce dividends have more positive changes than firms that did not reduce in all three years. Results are significant in years one and three. In the Z-score model, results are mixed. The only significant difference between firms that reduced dividends and those that did not is in year three with dividend reducers having a more negative change in capital expenditures. 
Table 5. Comparison of changes in Capital Expenditures/Total Assets

\begin{tabular}{|c|c|c|c|c|}
\hline \multicolumn{5}{|l|}{ based on two years losses } \\
\hline & Year 0 & Year 0-1 & Year $1-2$ & Year 2-3 \\
\hline Distressed, Reduced (5) & 0.0261 & 0.0006 & $0.0053 * * *$ & 0.0020 \\
\hline Distressed, Not Reduced (6) & 0.0526 & -0.0062 & -0.0049 & $0.0042 * *$ \\
\hline Not Distressed, Reduced (7) & 0.0455 & -0.0003 & 0.0007 & 0.0008 \\
\hline Not Distressed, Not Reduced (8) & 0.0541 & $-0.0017 * * *$ & -0.0005 & -0.0006 \\
\hline Distressed, Reduced vs. Distressed, Not Reduced (5-6) & $-0.0266 * * *$ & 0.0068 & $0.0101^{*}$ & $-0.0022 * * *$ \\
\hline $\begin{array}{l}\text { Not Distressed, Reduced vs. Not Distressed, Not } \\
\text { Reduced (7-8) }\end{array}$ & $-0.0086 * * *$ & $0.0014^{*}$ & 0.0011 & $0.0014 * * *$ \\
\hline \multicolumn{5}{|l|}{ based on z-score } \\
\hline & Year 0 & Year 0-1 & Year 1-2 & Year 2-3 \\
\hline Distressed, Reduced (5) & 0.0551 & -0.0004 & -0.0003 & $0.0017 * *$ \\
\hline Distressed, Not Reduced (6) & 0.0639 & $-0.0012 *$ & -0.0008 & $-0.0021 * * *$ \\
\hline Not Distressed, Reduced (7) & 0.0520 & 0.0011 & 0.0013 & $-0.0041 * *$ \\
\hline Not Distressed, Not Reduced (8) & 0.0616 & 0.0012 & -0.0017 & -0.0018 \\
\hline Distressed, Reduced vs. Distressed, Not Reduced (5-6) & $-0.0088 * * *$ & 0.0008 & 0.0005 & $0.0038 * * *$ \\
\hline $\begin{array}{l}\text { Not Distressed, Reduced vs. Not Distressed, Not } \\
\text { Reduced (7-8) }\end{array}$ & $-0.0095 * * *$ & -0.0001 & 0.0030 & $-0.0023 * * *$ \\
\hline
\end{tabular}

Notes: One tail t-test, $* 10$ percent level, $* * 5$ percent level, and $* * * 1$ percent level

\subsection{Liquidity}

Results for our test of liquidity are reported in Table 6. These results support our hypothesis for both distressed and non-distressed firms. In the two years of losses model, the change in cash to total assets is significantly greater in years one and two and significantly less in year three for distressed firms that reduced dividends compared to distressed firms that did not. Also, the change in cash to total assets is significantly greater in years one and two for non-distressed firms that reduced dividends compared to non-distressed firms that did not. In the Z-score model, the results were mostly not significant.

Table 6. Comparison of changes in Cash/Total assets

\begin{tabular}{lcccc}
\hline based on two years losses & & & & \\
& Year 0 & Year 0-1 & Year 1-2 & Year 2-3 \\
\cline { 2 - 5 } Distressed, Reduced (5) & 0.0892 & $0.0124^{* * *}$ & $0.0141^{* * *}$ & 0.0007 \\
Distressed, Not Reduced (6) & 0.0936 & $0.0060^{* *}$ & 0.0027 & $0.0068^{* *}$ \\
Not Distressed, Reduced (7) & 0.0945 & $0.0027^{* *}$ & $0.0014^{*}$ & 0.0006 \\
Not Distressed, Not Reduced (8) & 0.0832 & -0.0010 & $-0.0014^{*}$ & 0.0008 \\
Distressed, Reduced vs. Distressed, Not Reduced (5-6) & -0.0044 & $0.0064^{*}$ & $0.0115^{* * *}$ & $-0.0061^{* * *}$ \\
Not Distressed, Reduced vs. Not Distressed, Not & $0.0114^{* * *}$ & $0.0037^{* * *}$ & $0.0029^{* *}$ & -0.0001 \\
Reduced (7-8) & & & & \\
\hline based on Z-score & & & & \\
\hline & Year 0 & Year 0-1 & Year 1-2 & Year 2-3 \\
\cline { 2 - 5 } Distressed, Reduced (5) & 0.0465 & 0.0018 & 0.0012 & 0.0014 \\
Distressed, Not Reduced (6) & 0.0493 & 0.0007 & 0.0008 & 0.0015 \\
Not Distressed, Reduced (7) & 0.2346 & -0.0017 & -0.0025 & 0.0037 \\
Not Distressed, Not Reduced (8) & 0.1463 & $-0.0062^{* *}$ & 0.0021 & 0.0010 \\
Distressed, Reduced vs. Distressed, Not Reduced (5-6) & -0.0025 & 0.0012 & 0.0003 & -0.0000 \\
Not Distressed, Reduced vs. Not Distressed, Not & $0.0882^{* * *}$ & 0.0046 & -0.0046 & $0.0028^{* * *}$ \\
Reduced (7-8) & & & & \\
\hline Nit One & & & \\
\hline
\end{tabular}

Notes: One tail t-test, $* 10$ percent level, $* * 5$ percent level, and $* * * 1$ percent level 


\subsection{Capital}

Results of our test of the ability to raise capital are reported in Tables 7-9. Results in Table 7 indicate support for a one-year increase in sales growth for dividend reducers relative to those firms that did not reduce dividends in both distressed and non-distressed firms. Results after the first year are less conclusive. Tables 8 and 9 do not provide any statistically significant evidence in support of our hypothesis.

Table 7. Comparison of changes in Sales Growth

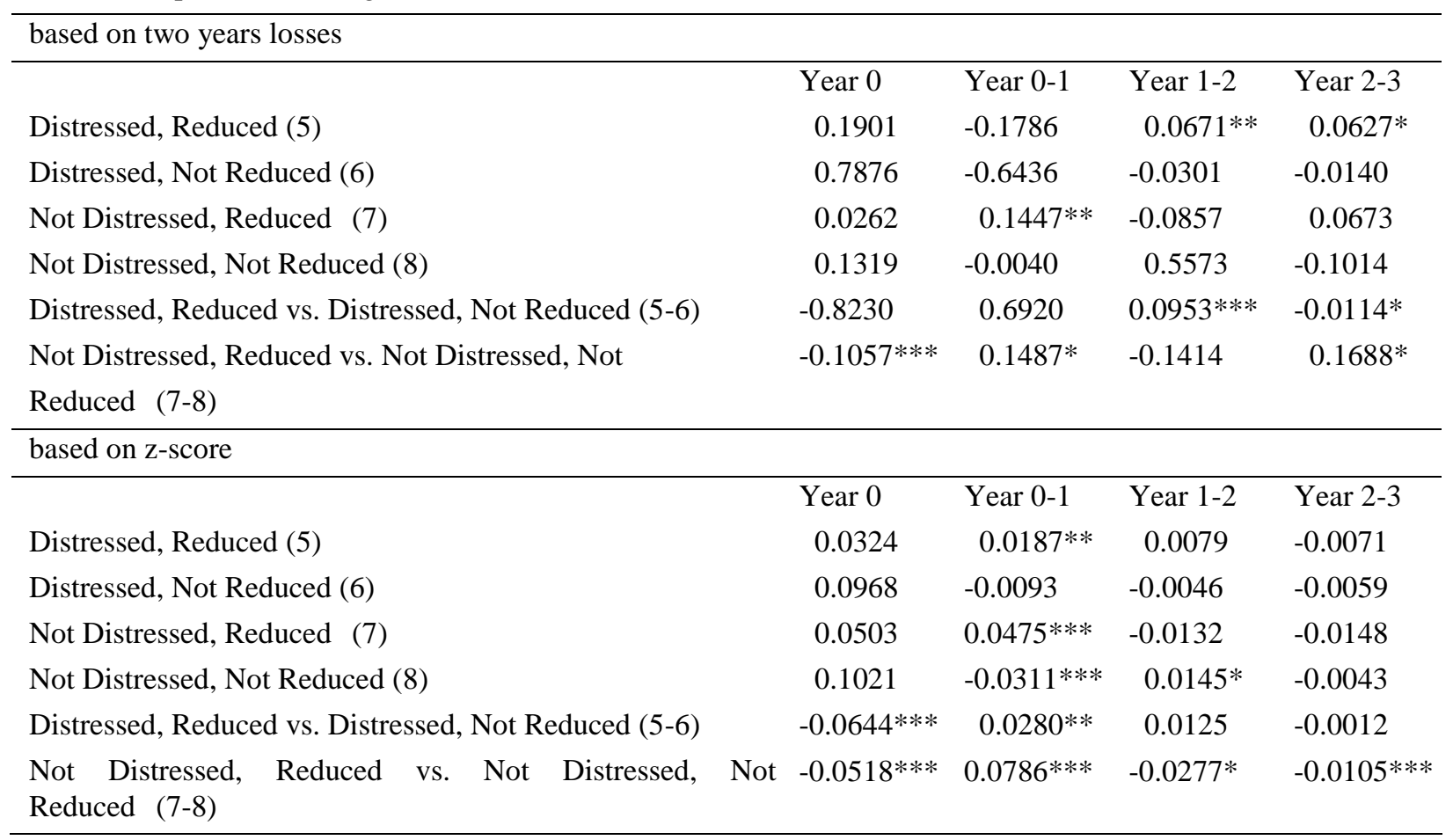

Notes: One tail t-test, $* 10$ percent level, $* * 5$ percent level, and $* * * 1$ percent level

Table 8. Comparison of changes in Total Liabilities/CSHE

\begin{tabular}{|c|c|c|c|c|c|}
\hline \multicolumn{6}{|l|}{ based on two years losses } \\
\hline & & Year 0 & Year 0-1 & Year 1-2 & Year 2-3 \\
\hline Distressed, Reduced (5) & & 8.4651 & 4.7702 & -9.0232 & $-0.2869 * * *$ \\
\hline Distressed, Not Reduced (6) & & 5.0714 & -1.0740 & -0.3366 & -0.0587 \\
\hline Not Distressed, Reduced (7) & & 5.0748 & 10.2804 & -0.1222 & -9.8301 \\
\hline Not Distressed, Not Reduced (8) & & 4.3818 & -0.5466 & $0.7135^{*}$ & -0.3655 \\
\hline Distressed, Reduced vs. Distressed, Not Reduced (5-6) & & $3.3937 *$ & 5.8442 & -8.6866 & -0.2282 \\
\hline $\begin{array}{l}\text { Not Distressed, Reduced vs. Not Distressed, } \\
\text { Reduced (7-8) }\end{array}$ & Not & 0.6929 & 10.8270 & -0.8357 & -9.4646 \\
\hline \multicolumn{6}{|l|}{ based on z-score } \\
\hline & & Year 0 & Year 0-1 & Year 1-2 & Year 2-3 \\
\hline Distressed, Reduced (5) & & 2.5413 & 0.0765 & $0.2117 *$ & -0.0675 \\
\hline Distressed, Not Reduced (6) & & 2.0859 & -0.0052 & 0.9075 & -0.8743 \\
\hline Not Distressed, Reduced (7) & & 2.0796 & $0.5542 *$ & -0.0535 & 0.0276 \\
\hline Not Distressed, Not Reduced (8) & & 0.9528 & -0.0816 & $0.0981 * *$ & 0.0616 \\
\hline Distressed, Reduced vs. Distressed, Not Reduced (5-6) & & $0.4554 * * *$ & 0.0817 & -0.6958 & 0.8059 \\
\hline $\begin{array}{l}\text { Not Distressed, Reduced vs. Not Distressed, } \\
\text { Reduced (7-8) }\end{array}$ & Not & $1.1268 * *$ & $0.6358^{*}$ & -0.1517 & -0.0340 \\
\hline
\end{tabular}

Notes: One tail t-test, $* 10$ percent level, $* * 5$ percent level, and $* * * 1$ percent level 
Table 9. Comparison of changes in Retained Earnings/Common Stockholders' Equity

\begin{tabular}{|c|c|c|c|c|c|}
\hline \multicolumn{6}{|l|}{ based on two years losses } \\
\hline & & Year 0 & Year $0-1$ & Year 1-2 & Year 2-3 \\
\hline Distressed, Reduced (5) & & 0.6560 & 0.0604 & -0.0188 & -0.0918 \\
\hline Distressed, Not Reduced (6) & & 0.6261 & $-0.0180 * *$ & 0.0009 & $0.0153 * * *$ \\
\hline Not Distressed, Reduced (7) & & 0.6502 & -0.0060 & 0.1140 & -0.0937 \\
\hline Not Distressed, Not Reduced (8) & & 0.7624 & -0.0192 & $0.0067 *$ & $0.0513 *$ \\
\hline Distressed, Reduced vs. Distressed, Not Reduced (5-6) & & 0.0299 & 0.0783 & -0.0197 & -0.1070 \\
\hline $\begin{array}{l}\text { Not Distressed, Reduced vs. Not Distressed, } \\
\text { Reduced }(7-8)\end{array}$ & Not & $-0.1122 * * *$ & 0.0132 & 0.1073 & $-0.1450 *$ \\
\hline \multicolumn{6}{|l|}{ based on z-score } \\
\hline & & Year 0 & Year $0-1$ & Year 1-2 & Year 2-3 \\
\hline Distressed, Reduced (5) & & 0.5866 & -0.0037 & $0.0087 * *$ & $0.0070 * *$ \\
\hline Distressed, Not Reduced (6) & & 0.7094 & -0.0276 & 0.0163 & 0.0183 \\
\hline Not Distressed, Reduced (7) & & 0.8597 & -0.0169 & 0.5051 & -0.5000 \\
\hline Not Distressed, Not Reduced (8) & & 0.8767 & $0.0104 * *$ & 0.0081 & $0.0122 *$ \\
\hline Distressed, Reduced vs. Distressed, Not Reduced (5-6) & & $-0.1227 * *$ & 0.0239 & -0.0076 & -0.0114 \\
\hline $\begin{array}{l}\text { Not Distressed, Reduced vs. Not Distressed, Not } \\
\text { Reduced (7-8) }\end{array}$ & & -0.0170 & $-0.0273 *$ & 0.4970 & -0.5122 \\
\hline
\end{tabular}

Notes: One tail t-test, $* 10$ percent level, $* * 5$ percent level, and $* * * 1$ percent level

\subsection{Profitability}

Results of our test of profitability are reported in Table 10. Contrary to our expectations, distressed firms experience an increase in profitability in the two years following a dividend reduction. In the model using two years of losses, distressed firms that did not reduce dividends also experienced a significant positive change in return on assets. Comparing the two groups, distressed firms that reduced dividends had a significantly positive change in ROA compared to distressed firms that did not reduce dividends in the first year and a significantly negative change in the third year. In the Z-score model, distressed dividend-reducing firms had significantly positive changes relative to nonreducing firms in both years one and two.

With respect to non-distressed firms, both models show significant positive changes for dividend reducing firms in the first year only.

Table 10. Comparison of changes in ROA

\begin{tabular}{|c|c|c|c|c|}
\hline \multicolumn{5}{|l|}{ based on two years losses } \\
\hline & Year 0 & Year $0-1$ & Year 1-2 & Year 2-3 \\
\hline Distressed, Reduced (5) & 0.0345 & $0.0179 * * *$ & $0.0129 * * *$ & 0.0019 \\
\hline Distressed, Not Reduced (6) & 0.0446 & $0.0122 * * *$ & $0.0106 . * * *$ & $0.0042 * *$ \\
\hline Not Distressed, Reduced (7) & 0.1472 & $0.0194 * * *$ & 0.0750 & 0.0010 \\
\hline Not Distressed, Not Reduced (8) & 0.1118 & $-0.0024 * *$ & -0.0001 & $-0.0027 * *$ \\
\hline Distressed, Reduced vs. Distressed, Not Reduced (5-6) & $-0.0101 * * *$ & $0.0057 * *$ & 0.0022 & $-0.0022 * * *$ \\
\hline $\begin{array}{l}\text { Not Distressed, Reduced vs. Not Distressed, Not } \\
\text { Reduced }(7-8)\end{array}$ & $0.0354 * * *$ & $0.0218 * * *$ & 0.0752 & 0.0037 \\
\hline \multicolumn{5}{|l|}{ based on z-score } \\
\hline & Year 0 & Year $0-1$ & Year 1-2 & Year 2-3 \\
\hline Distressed, Reduced (5) & 0.0770 & $0.0037 * * *$ & $0.0025 * *$ & -0.0011 \\
\hline Distressed, Not Reduced (6) & 0.0985 & $-0.0012 *$ & $-0.0012 *$ & $-0.0018 * *$ \\
\hline Not Distressed, Reduced (7) & 0.2945 & $0.0339 * * *$ & -0.0124 & -0.0038 \\
\hline Not Distressed, Not Reduced (8) & 0.1775 & -0.0024 & $-0.0068 * *$ & -0.0008 \\
\hline Distressed, Reduced vs. Distressed, Not Reduced (5-6) & $-0.0215 * * *$ & $0.0050 * * *$ & $0.0037 * *$ & 0.0007 \\
\hline $\begin{array}{l}\text { Not Distressed, Reduced vs. Not Distressed, Not } \\
\text { Reduced (7-8) }\end{array}$ & $0.1170 * * *$ & $0.0363 * * *$ & -0.0056 & -0.0031 \\
\hline
\end{tabular}

Notes: One tail t-test, $* 10$ percent level, $* * 5$ percent level, and $* * * 1$ percent level 


\subsection{Summary of Findings}

Table 11 contains a summary of our results. Contrary to expectations, effects of dividend reductions for distressed firms as measured by our accounting ratios are positive for all measures. Distressed firms that make dividend reductions gain more value, make greater capital expenditures, have higher liquidity and sales growth, and are more profitable in the years following the dividend reduction than distressed firms that do not reduce dividends. Contrary to expectations, results are similar for non-distressed firms that reduce dividends relative to firms that do not, except with respect to the value of the firm. Non-distressed firms that reduce dividends make greater capital expenditures, have higher liquidity and sales growth, and are more profitable in the years following the dividend reduction than non-distressed firms that do not reduce dividends. However, these firms also lose market value relative to non-distressed firms that do not reduce dividends. While this finding is consistent with the hesitation to reduce dividends, we had hoped to find costs associated with the dividend reduction that would explain both the reluctance to reduce dividends and the decline in market value that follows dividend reduction. We did not do so.

Table 11. Summary of Results of Test of Hypotheses

\begin{tabular}{lllll}
\hline Hypothesis & Measure & Distressed or Not & Predicted Sign & Result \\
\hline Value & Market/Sales & Distressed & - & + \\
& & Not Distressed & - & + \\
Market/Book & Distressed & - & + \\
Opportunity & Cap Ex/Assets & Not Distressed & - & + \\
Liquidity & & Distressed & + & + \\
& Cash/Assets & Not Distressed & + & + \\
Capital & Distressed & + & + \\
& Sales Growth & Not Distressed & + & + \\
& & Distressed & - & + \\
& Liabilities/CSE & Not Distressed & & + \\
& & Distressed & - & + \\
Profitability & RE/SE & Not Distressed & & + \\
& & Distressed & - & + \\
& & Not Distressed & & + \\
& & Distressed & - & + \\
& & Not Distressed & & + \\
& & &
\end{tabular}

\section{Conclusion}

We are interested in the costs of dividend reductions on distressed and non-distressed firms. We speculated that these costs could explain the reluctance of firms to reduce dividends. We failed to find any costs to the firm of a reduction of dividends beyond the reduction in firm value for non-distressed firms. That reduction in firm value is already well documented in the literature.

Our research design compared the costs to firms that reduced dividends relative to firms that did not reduce dividends expecting to find a cost to the dividend reduction. This is a fundamental weakness in our research design. It may be that firms that would experience a cost to the dividend reduction did not reduce dividends. Future research might focus on firms with declining earnings and investigate the differences between those that reduce dividends and those that do not.

\section{References}

Aharony, J. \& Swary, I. (1980). Quarterly Dividend and Earning Announcements and Stockholders' Returns: An Empirical Analysis. The Journal of Finance, 35, 1-12. https://doi.org/10.1111/j.1540-6261.1980.tb03466.x

Altman, E. (1968). Financial Ratios, Discriminant Analysis, and the Prediction of Corporate Bankruptcy, The Journal of Finance, 23, 589-609. https://doi.org/10.1111/j.1540-6261.1968.tb00843.x 
Altman, E. I., Danovi, A., \& Falini, A. (2013). Z-Score Models' Application to Italian Companies Subject to Extraordinary Administration. Journal of Applied Finance, 23, 1-10. https://ssrn.com/abstract=2686750

Baker, K. \& Smith, D. (2006). In Search of a Residual Dividend Policy. Review of Financial Economics, 15, 1-18. https://doi.org/10.1016/j.rfe.2004.10.002

Bhagat, S., Moyen, N., \& Suh, I. (2005). Investment and Internal Funds of Distressed Firms. Journal of Corporate Finance, 11, 449-472. https://doi.org/10.1016/j.jcorpfin.2004.09.002

Brook, Y., Charton, W. \& Hendershott, R. (1998). Do Firms Use Dividends to Signal Large Future Cash Flow Increases? Financial Management, 27, 46-57. . https://doi.org/10.2307/3666274

Cohen, G. \& Yagil, J. (2009). Why Do Financially Distressed Firms Pay Dividends? Applied Economic Letters, 16, 1201-1204. https://doi.org/10.1080/17446540802389057

Grullon, G., Michaely, R. \& Swaminathan, B. (2002). Are Dividend Changes a Sign of Firm Maturity? Journal of Business, 75, 387-424. https://doi.org/10.1086/339889

Healy, P. \& Palepu, K. (1988). Earnings Information Conveyed by Dividend Initiations and Omissions. Journal of Financial Economics, 21, 149-175. https://doi.org/10.1016/0304-405X(88)90059-1

Lee, B. S. \& Yau, N. A. (2003). The Market's Differential Reactions to Forward-Looking and Backward-Looking Dividend Changes. The Journal of Financial Research, 26, 449-468. https://doi.org/10.1111/1475-6803.00068

Michaely, R., Thaler, R., \& Womack, K. (1995). Price Reactions to Dividend Initiations and Omissions: Overreaction or Drift? The Journal of Finance, 50, 573-608. https://doi.org/10.1111/j.1540-6261.1995.tb04796.x 